\title{
Diprosopus twin
}

\section{*Pradipprava Paria ${ }^{1}$, Ramesh Chandra Halder ${ }^{2}$, Sibarjun Ghosh ${ }^{3}$}

Sri Lanka Journal of Child Health, 2016; 45(3): 231-232

DOI: http://dx.doi.org/10.4038/sljch.v45i3.8002

(Key words: Diprosopus twin)

\section{Case report}

A female baby of a consanguineous parentage, was delivered at 32 weeks with a birth weight of $1.4 \mathrm{~kg}$. Examination showed that the baby had two fused faces with two mouths, two noses, two lateral completely formed eyes and two medially fused eyes

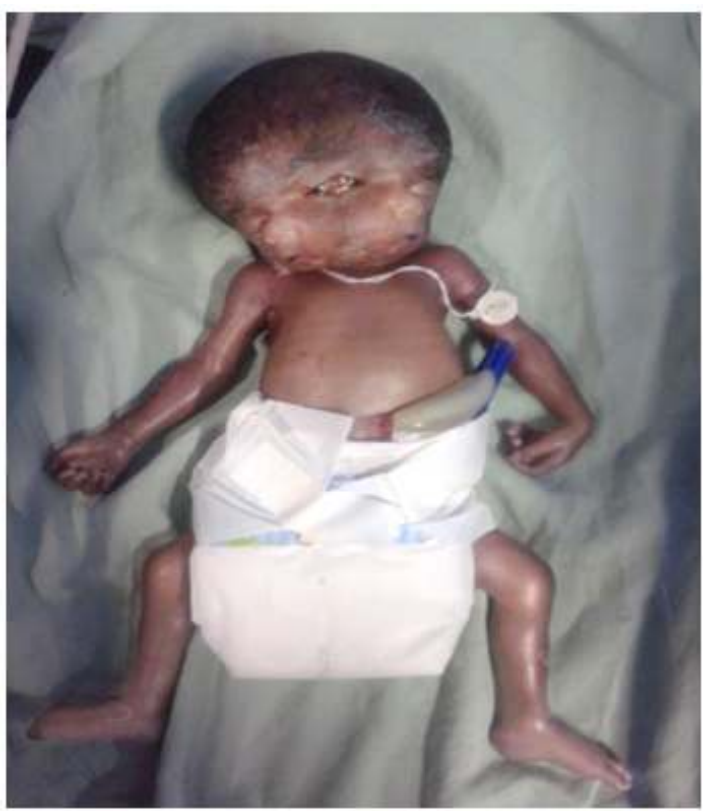

Figure 1: Diprosopus twin showing joined faces with single torso, a pair of upper limbs and a pair of lower limbs (Signed informed consent obtained from parent to publish picture)

${ }^{1}$ RMO-cum-Clinical Tutor, ${ }^{2} R M O,{ }^{3}$ Professor \& $H O D$, Department of Paediatric Medicine, $R$ G Kar Medical College, Kolkata, India

*Correspondence: drpradip83@gmail.com

(Received on 07 August 2015: Accepted after revision on 18 September 2015)

The authors declare that there are no conflicts of interest

Personal funding was used for this project.

Open Access Article published under the Creative Commons Attribution CC-BY (CC)

without any eyelids, but having one body and two pairs of limbs (Figure 1). Baby died 5 minutes after birth and was diagnosed as diprosopus twinning.

\section{Discussion}

Diprosopus, also known as craniofacial duplication, is the rarest form of conjoined twins, with prevalence of 1 in $15,000,000$ births $^{1}$. The baby is born with a single torso and normal limbs but the facial features are duplicated to varying degrees ${ }^{2}$. Most babies are delivered stillborn. There are fewer than 50 cases documented since $1864^{1}$. Although classically considered conjoined twinning (which it resembles), this anomaly is not normally due to the fusion or incomplete separation of two embryos. It is the result of abnormal activity by the protein sonic hedgehog $(\mathrm{SHH})^{3}$. SHH is responsible for signalling and craniofacial patterning during embryonic development. Where the protein is found in excess, a baby will have wider facial features, and in extreme cases it can cause the duplication of those features.

Diprosopus can be detected antenatally by ultrasound examination for which the first indication is polyhydroamnios ${ }^{4}$. It often occurs in combination with other congenital disorders, particularly anencephaly, neural tube defect and cardiac malformations ${ }^{5}$. When present, the brain may show abnormalities ranging from partial to complete duplication of brain structures, and under development of brain tissues. The condition is a rarity and currently no treatment to cure the condition is known.

\section{References}

1. Picaud A, Nlome-Nze AR, Engongha-Beka $\mathrm{T}$, Ogowet-Igumu N. Early prenatal diagnosis of diprosopic syncephalic joined twins. Rev Fr Gynecol Obstet 1990; 85:37981.

PMid: 2202040

2. al Muti Zaitoun A, Chang J, Booker M. (1999). Diprosopus (partially duplicated head) associated with anencephaly: a case 
report. Pathology, Research and Practice 1999; 195 (1): 45-50.

http://dx.doi.org/10.1016/S03440338(99)80

094-6

3. Hu D, Helms JA. The role of sonic hedgehog in normal and abnormal craniofacial morphogenesis. Development 1999; 126 (21): 4873-84.

PMid: 10518503

4. DeRuiter C. Diprosopus (craniofacial duplication). Embryo Project Encyclopedia (2011-08-16). ISSN: 1940-5030. Available from:

http://www.embryo.asu.edu/handle/10776/2

286.
5. Laor T, Stanek J, Leach JL. Diprosopustetraophthalmus: $\mathrm{CT}$ as a complement to autopsy. British Journal of Radiology 2012; 85(1009): e10-3 http://dx.doi.org/10.1259/bjr/79093458

PMid: 22190755 PMCid: PMC3473930 